\title{
Comparison of clinicopathologic parameters and oncologic outcomes between type 1 and type 2 papillary renal cell carcinoma
}

\author{
Xiang Le ${ }^{1 \dagger}$, Xiang-Bo Wang $^{2+}$, Hao Zhao ${ }^{1}$, Ren-Fu Chen ${ }^{1 *}$ and Peng Ge 1* $^{1^{*}}$
}

\begin{abstract}
Background: To compare the clinicopathologic parameters and oncologic outcomes between type 1 and type 2 papillary renal cell carcinoma (PRCC).

Methods: This study was approved by the review board (NO.XYFY2019-KL032-01). Between 2007 and 2018, 52 consecutive patients who underwent surgery at a single tertiary referral hospital were included. Clinicopathologic and survival data were collected and entered into a database. The Kaplan-Meier method, and univariate and multivariate Cox proportional hazard regression analyses were performed to estimate progression-free survival (PFS) and cancer-specific survival (CSS).

Results: Of the 52 patients, 24 (46.2\%) were diagnosed with type 1 PRCC, and 28 (53.8\%) had type 2 PRCC. The mean tumor size was $4.8 \pm 2.5 \mathrm{~cm}$. The two subtypes displayed different morphological features: foamy macrophages were more common in type 1 PRCC, while eosinophils and microvascular angiolymphatic invasion were more frequent in type 2 PRCC. Type 2 cases showed higher tumor stage and World Health Organization/ International Society of Urological Pathology (WHO/ISUP) grade than type 1 cases (T3-T4: 43\% vs 17\%, P=0.041; G3G4: $43 \%$ vs $8 \%, P=0.005)$. In univariate analysis, type 2 PRCC had a lower probability for PFS and CSS than patients with type 1 PRCC ( $P=0.016, P=0.049$, log-rank test, respectively). In multivariate analysis, only WHO/ISUP grade (HR $11.289,95 \% \mathrm{Cl} 2.303-55.329, P=0.003)$ and tumor size (HR 1.244, 95\% Cl 1.034-1.496, $P=0.021$ ) were significantly associated with PFS.

Conclusions: PRCC subtype displayed different morphological features: foamy macrophages, eosinophils and microvascular angiolymphatic invasion are pathologic features that may aid in the distinction of the two subtypes. Histologic subtype of PRCC is not an independent prognostic factor and only WHO/ISUP grade and tumor size were independent predictors for PFS.
\end{abstract}

Keywords: Papillary renal cell carcinoma, WHO/ISUP grade, Prognosis, Subtype

\footnotetext{
*Correspondence: Renfu_chen@aliyun.com; gepengyzu@126.com

${ }^{+}$Xiang Le and Xiang-Bo Wang contributed equally to this work.

'Department of Urology, the Affiliated Hospital of Xuzhou Medical University, Xuzhou, Jiangsu, China

Full list of author information is available at the end of the article
}

(c) The Author(s). 2020 Open Access This article is licensed under a Creative Commons Attribution 4.0 International License, which permits use, sharing, adaptation, distribution and reproduction in any medium or format, as long as you give appropriate credit to the original author(s) and the source, provide a link to the Creative Commons licence, and indicate if changes were made. The images or other third party material in this article are included in the article's Creative Commons licence, unless indicated otherwise in a credit line to the material. If material is not included in the article's Creative Commons licence and your intended use is not permitted by statutory regulation or exceeds the permitted use, you will need to obtain permission directly from the copyright holder. To view a copy of this licence, visit http://creativecommons.org/licenses/by/4.0/. The Creative Commons Public Domain Dedication waiver (http://creativecommons.org/publicdomain/zero/1.0/) applies to the data made available in this article, unless otherwise stated in a credit line to the data. 


\section{Background}

Papillary renal cell carcinoma (PRCC), the second most common renal cell carcinoma (RCC) following clear cell RCC, accounts for 6 to $18 \%$ of all RCC cases [1]. It is a markedly heterogeneous entity characterized by different histologic subtypes, disease progression and clinical outcomes [2, 3]. Delahunt and Eble initially subclassified the PRCC into type 1 and type 2 based on morphological and immunohistochemical features in 1997 [4]. Typically, type 1 demonstrates the papillae covered by a single layer of simple cuboidal epithelia with scant cytoplasm, while type 2 is characterized by the presence of nuclear pseudostratifcation [5].

Recently, Magers et al. showed that type 1 PRCC was more likely to have clear cytoplasm and nuclear grooves, whereas type 2 PRCC had more abundant, granular cytoplasm and a higher nuclear grade [6]. Leroy et al. suggested that MUC1 immunostaining was usually positive in type 1 PRCC, which might be helpful in classifying such tumors [7]. However, due to the overlaps in morphologic, immunohistochemical and molecular features, it is difficult to classify all PRCCs into subtypes absolutely with current controversial criteria $[2,6,8]$.

The issue whether the histologic subtypes affect oncological outcomes remains in debate. Some studies suggested type 1 PRCC was associated with a lower nuclear grade, lower tumor stage, and better prognosis than type 2 PRCC [9]. However, some other studies showed almost similar prognosis across the two subtypes $[10,11]$.

Herein, we performed the present study in an attempt to compare the clinicopathologic parameters and oncologic outcomes between type 1 and type 2 PRCC using a homogeneous pathological entity.

\section{Methods}

\section{Patient population and pathologic evaluation}

This was a retrospective, single-institution study approved by the Affiliated Hospital of Xuzhou Medical University review board (NO.XYFY2019-KL032-01). A total of 56 tumors initially diagnosed as PRCC between 2007 and 2018 at a single tertiary hospital were evaluated. All hematoxylin and eosin-stained slides available were reviewed by the same pathologist (author Xiang-Bo Wang). Histologic subtypes were recorded according to the WHO classification of kidney tumors [12]. Four cases were excluded from the study after review. The remaining 52 patients were included in the present study.

Because of the difficulties in validation, reproducibility, and interpretation of the Fuhrman system [13], all samples were re-graded according to the four-tiered World Health Organization/International Society of Urological Pathology (WHO/ISUP) grading system [14, 15]. Pathological stage was assigned according to the American
Table 1 Clinical characteristics between type 1 and type 2 papillary renal cell carcinoma

\begin{tabular}{|c|c|c|c|}
\hline & Type 1 PRCC & Type 2 PRCC & $P$ \\
\hline \multicolumn{4}{|l|}{ Gender } \\
\hline Male & $18(75.0 \%)$ & $20(71.4 \%)$ & 0.772 \\
\hline Female & $6(25.0 \%)$ & $8(28.6 \%)$ & \\
\hline Age (years) & $53.4 \pm 12.6$ & $55.8 \pm 15.5$ & 0.552 \\
\hline Tumor size (cm) & $4.6 \pm 2.26$ & $4.9 \pm 2.76$ & 0.683 \\
\hline \multicolumn{4}{|c|}{ Cell-based immunotherapy ${ }^{a}$} \\
\hline Yes & $3(12.5 \%)$ & $5(17.9 \%)$ & 0.882 \\
\hline No & $21(87.5 \%)$ & $23(82.1 \%)$ & \\
\hline \multicolumn{4}{|l|}{ WHO/ISUP grade } \\
\hline $\mathrm{G} 1 / \mathrm{G} 2$ & $22(91.7 \%)$ & $16(57.1 \%)$ & 0.005 \\
\hline $\mathrm{G} 3 / \mathrm{G} 4$ & $2(8.3 \%)$ & $12(42.9 \%)$ & \\
\hline \multicolumn{4}{|l|}{ Tumor stage $(T)$} \\
\hline $\mathrm{T} 1 / \mathrm{T} 2$ & $20(83.3 \%)$ & $16(57.1 \%)$ & 0.041 \\
\hline $\mathrm{T} 3 / \mathrm{T} 4$ & $4(16.7 \%)$ & $12(42.9 \%)$ & \\
\hline \multicolumn{4}{|l|}{ Type of surgery } \\
\hline Radical nephrectomy & $8(33.3 \%)$ & 17 (60.7\%) & 0.049 \\
\hline Partial nephrectomy & $16(66.7 \%)$ & $11(39.3 \%)$ & \\
\hline \multicolumn{4}{|l|}{ Surgical approach } \\
\hline Open surgery & $3(12.5 \%)$ & 9 (32.1\%) & 0.094 \\
\hline Laparoscopic surgery & $21(87.5 \%)$ & 19 (67.9\%) & \\
\hline \multicolumn{4}{|l|}{ Disease progression } \\
\hline Yes & $1(4.0 \%)$ & 9 (33.3\%) & 0.028 \\
\hline No & $22(96.0 \%)$ & $18(66.7 \%)$ & \\
\hline \multicolumn{4}{|l|}{ Death from tumor } \\
\hline Yes & $0(0.0 \%)$ & $6(22.2 \%)$ & 0.048 \\
\hline No & $23(100.0 \%)$ & $21(77.8 \%)$ & \\
\hline
\end{tabular}

Abbreviations: WHO/ISUP World Health Organization/International Society of Urological Pathology, PRCC Papillary renal cell carcinoma

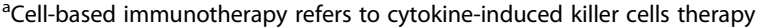

Joint of Committee on Cancer staging manual [10]. More morphological parameters were also recorded, including foamy macrophages, hemosiderin laden macrophages, necrosis, sarcomatoid differentiation, eosinophils, hyaline cells, classic papillary architecture, solid architecture, tubular architecture, perinephric/renal sinus fat invasion, and microvascular angiolymphatic invasion $[6,16]$.

Patient's clinicopathologic characteristics were entered into a database. Postoperative follow-up was not standardized. Generally, patients were evaluated every 3 months during the first year, every 6 months during the next 2 years, and then annually. Follow-up included physical examinations, laboratory measurements and imaging studies unless otherwise clinically indicated. The last follow-up was performed in May 2019. The outcomes of interest were progression-free survival (PFS) 
and cancer-specific survival (CSS). PFS was defined as the time from the date of surgery to local recurrence or distant metastasis and CSS was defined as the time from the date of surgery to a kidney cancer-related death. Surviving patients were censored at the last follow-up.

\section{Statistical analysis}

The continuous variables were compared using the independent-sample $\mathrm{t}$ test and the categorical variables were compared using the $x^{2}$ - test. The KaplanMeier method was used to estimate the impacts of the subclassification and clinicopathologic parameters of PRCC on PFS and CSS, and the comparison was made with log-rank test. Univariate and multivariate (stepwise selection with enter and remove limits of $P=0.05$ and $P=0.05$, respectively) Cox proportional hazards regression analyses were performed to evaluate independency of prognostic factors for PFS and CSS. Nine variables (gender, age, WHO/ISUP grade, cell-based immunotherapy, type of surgery, surgical approach, pathological stage, PRCC subtypes and tumor size) were used in the stepwise selection analysis. Two-sided $P<0.050$ was considered to indicate a statistically significant difference. Statistical analysis was performed using the Statistical Analysis System version 9.4 (SAS Institute, Cary, NC, USA) or Statistical Package for the Social Sciences 25.0 software (SPSS Inc., Chicago, IL, USA).

\section{Results}

Association with clinicopathologic characteristics

After histopathological review, the diagnosis of PRCC was confirmed in a total of 52 patients, including 38 males and 14 females (Table 1). The mean tumor size was $4.8 \pm 2.5 \mathrm{~cm}$. There were $24(46.2 \%)$ patients with type 1 PRCC and 28 (53.8\%) patients with type 2 PRCC. The age at surgery ranged from 17 to 86 years old (mean: 55.1). According to Table 1, patients with type 2 PRCC were more likely to have a higher WHO/ISUP grade (G3-4 in type 2 vs type 1: $43 \%$ vs $8 \%, P=0.005)$ and an advanced tumor stage (T3-4 in type 2 vs type $1: 43 \%$ vs $17 \%, P=0.041$, Fig. 1 ). Moreover, patients with type 2 PRCC were more likely to receive radical nephrectomy (61\% vs $33 \%$; $P=0.049$ ). Other clinical characteristics (including gender distribution, age, tumor size, and cell-based immunotherapy) demonstrated no statistically significant differences across the two groups.

Table 2 displays the pathologic characteristics of the patients. Presence of foamy macrophages was more frequent in type $1(83 \%)$ than in type $2(57 \%)$ $(P=0.041)$. In contrast, eosinophils and microvascular angiolymphatic invasion were more frequent in type 2 PRCC ( $P=0.012$ and $P=0.028$, respectively). There were no statistically significant differences across the two groups in terms of hemosiderin laden macrophages, necrosis, sarcomatoid differentiation,

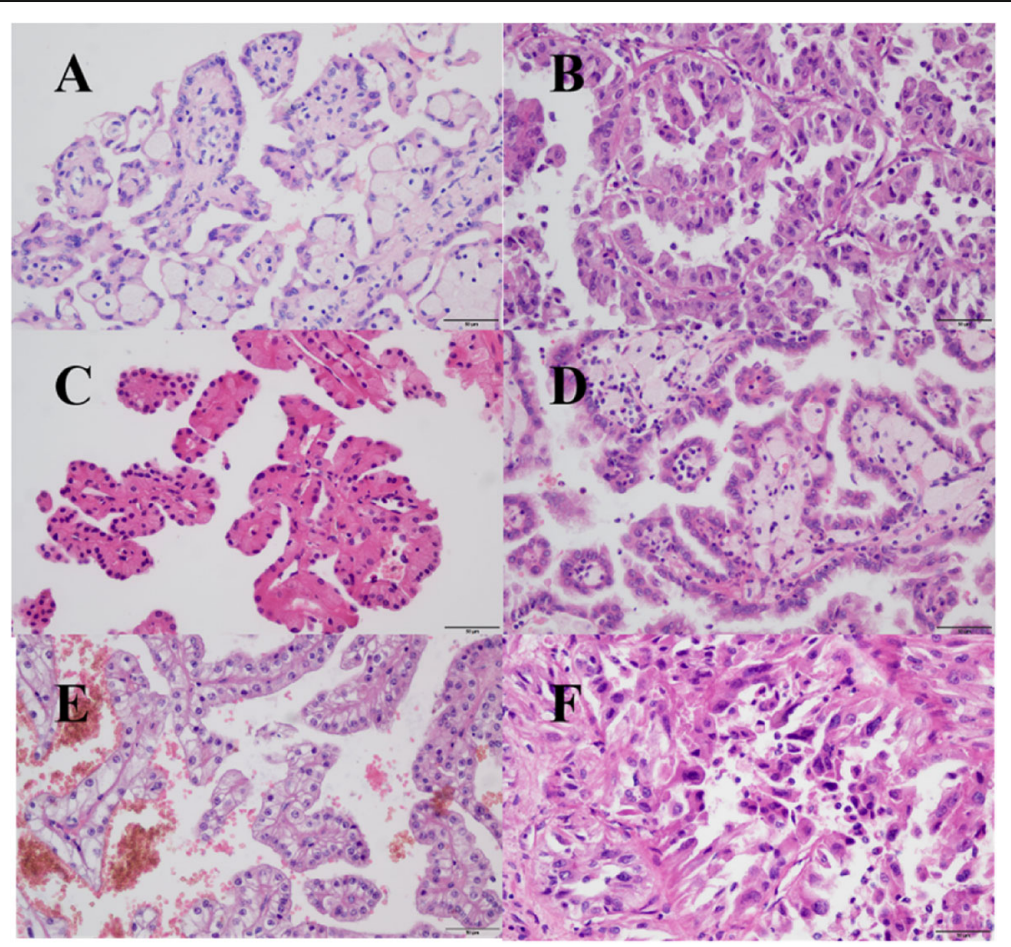

Fig. 1 Papillary renal cell carcinoma grading and types. a, type 1; b, type 2; Papillary renal cell carcinoma graded as nucleolar grade 1(c), 2(d), 3(e), 4(f). Hematoxylin and eosin stains, original magnification $\times 400$ 
Table 2 Pathologic characteristics between type 1 and type 2 papillary renal cell carcinoma

\begin{tabular}{|c|c|c|c|}
\hline & Type 1 & Type 2 & $\mathbf{P}$ \\
\hline \multicolumn{4}{|c|}{ Foamy macrophages } \\
\hline Yes & $20(83.3 \%)$ & $16(57.1 \%)$ & \multirow[t]{2}{*}{0.041} \\
\hline No & $4(16.7 \%)$ & $12(42.9 \%)$ & \\
\hline \multicolumn{4}{|c|}{ Hemosiderin laden macrophages } \\
\hline Yes & $20(83.3 \%)$ & $27(96.4 \%)$ & \multirow[t]{2}{*}{0.261} \\
\hline No & $4(16.7 \%)$ & $1(3.6 \%)$ & \\
\hline \multicolumn{4}{|c|}{ Necrosis } \\
\hline Yes & $11(45.8 \%)$ & $18(64.3 \%)$ & \multirow[t]{2}{*}{0.182} \\
\hline No & $13(54.2 \%)$ & $10(35.7 \%)$ & \\
\hline \multicolumn{4}{|c|}{ Sarcomatoid differentiation } \\
\hline Yes & $0(0.0 \%)$ & $2(7.1 \%)$ & \multirow[t]{2}{*}{0.493} \\
\hline No & $24(100.0 \%)$ & $26(92.9 \%)$ & \\
\hline \multicolumn{4}{|c|}{ Eosinophils } \\
\hline Yes & $7(29.2 \%)$ & $18(64.3 \%)$ & \multirow[t]{2}{*}{0.012} \\
\hline No & $17(70.8 \%)$ & $10(35.7 \%)$ & \\
\hline \multicolumn{4}{|c|}{ Hyaline cells } \\
\hline Yes & $12(50.0 \%)$ & $18(64.3 \%)$ & \multirow[t]{2}{*}{0.299} \\
\hline No & $12(50.0 \%)$ & $10(35.7 \%)$ & \\
\hline \multicolumn{4}{|c|}{ Classic papillary architecture } \\
\hline Yes & $23(95.8 \%)$ & $28(100.0 \%)$ & \multirow[t]{2}{*}{0.462} \\
\hline No & $1(4.2 \%)$ & $0(0.0 \%)$ & \\
\hline \multicolumn{4}{|c|}{ Solid architecture } \\
\hline Yes & $4(16.7 \%)$ & $10(35.7 \%)$ & \multirow[t]{2}{*}{0.123} \\
\hline No & $20(83.3 \%)$ & $18(64.3 \%)$ & \\
\hline \multicolumn{4}{|c|}{ Tubular architecture } \\
\hline Yes & $15(62.5 \%)$ & $16(57.1 \%)$ & \multirow[t]{2}{*}{0.695} \\
\hline No & $9(37.5 \%)$ & $12(42.9 \%)$ & \\
\hline \multicolumn{4}{|c|}{ Perinephric/renal sinus fat invasion } \\
\hline Yes & $3(12.5 \%)$ & $8(28.6 \%)$ & \multirow[t]{2}{*}{0.157} \\
\hline No & $21(87.5 \%)$ & $20(71.4 \%)$ & \\
\hline \multicolumn{4}{|c|}{ Microvascular angiolymphatic invasion } \\
\hline Yes & $1(4.2 \%)$ & $9(32.1 \%)$ & \multirow[t]{2}{*}{0.028} \\
\hline No & $23(95.8 \%)$ & $19(67.9 \%)$ & \\
\hline
\end{tabular}

hyaline cells, classic papillary architecture, solid architecture, tubular architecture, and perinephric/ renal sinus fat invasion.

\section{Association with survival}

Two patients were lost to follow-up after surgery. Thus, the remaining 50 patients were included in survival analysis. The mean follow-up duration was 38 months (standard error, 4.7). Overall, 9 (33\%) and 1 (4\%) patients with type 2 PRCC and type 1 PRCC underwent disease progression, respectively $(P=0.028$, Table 1$)$. A total of 6 patients died of PRCC. The most common recurrence or metastatic sites were retroperitoneal /distant lymph node, lung, liver, and retroperitoneal cavity (Table 3).

Figure 2a exhibits the Kaplan-Meier plots for PFS estimates stratified by type 1 PRCC versus type 2 . Type 2 PRCC patients had a lower probability for PFS than patients with type $1(P=0.016$, log-rank test, Fig. $2 \mathrm{a} ; P=$ 0.045, univariate Cox analysis, Table 4). Similarly, patients with type 2 PRCC were at significantly higher risk for cancer specific mortality than patients with type 1 PRCC ( $P=0.049$, Fig. 2b).

Multivariate analysis was performed using a Cox regression with stepwise selection of covariates. Among the nine variables (gender, age, WHO/ISUP grade, cellbased immunotherapy, type of surgery, surgical approach, pathological stage, PRCC subtypes and tumor size), only WHO/ISUP grade (HR 11.289, 95\% CI 2.303$55.329, P=0.003$ ) and tumor size (HR 1.244, 95\% CI 1.034-1.496, $P=0.021)$ entered the model. The histologic subtype of PRCC was not an independent predictor for PFS. In view of the fact that the statistical power was weakened by very few death events, multivariate Cox proportional hazards regression analyses were not performed for CSS.

\section{Discussion}

PRCC represents the largest subset of non-clear cell RCC [17]. It is traditionally subdivided into 2 subtypes on the basis of histomorphologic features. More recently, new PRCC subtype has been recognized [6]. In this current series, several morphological aspects of PRCC architecture and cytological features were investigated. We found that aggregates of foamy macrophages in the background stroma were common (69.2\% of cases) and presence of foamy macrophages was less frequent in type 2 PRCC (57.1\%) than type 1 PRCC (83.3\%). Similar to our findings, Polifka et al. demonstrated that $70.9 \%$ of type 1 PRCC and 49.0\% type 2 PRCC presented foamy macrophages and presence of foamy macrophages was linked with a better overall survival [18]. Unlike foamy macrophages, eosinophils and microvascular angiolymphatic invasion were more common in type 2 PRCC. Taken together, these findings in the present study may assist to discriminate between type 1 PRCC and type 2 PRCC.

The issue whether type 2 PRCC predicts poorer prognosis than type 1 PRCC remains controversial. Some claimed that type 2 has a more aggressive behavior than type 1, whereas others reported similar clinical course [9, 17-19]. From our perspectives, several points should be noted when we take the prior findings into consideration. Firstly, some studies investigated the prognosis of the subtypes after the data were adjusted against the 
Table 3 Recurrence and/or metastatic site in disease progression patients

\begin{tabular}{ll}
\hline Patient ID & Recurrence and/or metastatic site \\
\hline 1 & bone \\
2 & distant lymph node \\
3 & liver \\
5 & retroperitoneal lymph node, bone \\
6 & retroperitoneal lymph node, liver, bone \\
7 & retroperitoneal lymph node, rectum, retroperitoneal cavity \\
8 & lung,bone, brain \\
9 & retroperitoneal lymph node, lung, spleen, retroperitoneal cavity, abdominopelvic cavity, abdominal wall \\
10 & lung \\
\hline
\end{tabular}

effects of Fuhrman grade [10, 20]. Delahunt et al. indicated that Fuhrman grading was inappropriate for PRCC and recommended WHO/ISUP grading system [21]. Secondly, some investigations were based on multicenter database, thus without a centralized pathologic review, differing criteria and nomenclature likely resulted in under- or over-reporting of PRCC [10].

The present study was designed to investigate the outcomes of PRCC using a homogeneous pathological entity by minimizing potential confounding effects associated with different diagnosis criteria. We found that type 2 PRCC showed a higher tumor stage and a higher WHO/ISUP grade than type 1 PRCC. It indicates that type 2 PRCC tends to have a more aggressive course than type 1 PRCC, which is in accordance with the results of previous studies [9]. Regarding the prognostic factors, we found differences in terms of PFS and CSS between type 1 and type 2 in univariate analysis. However, multivariate analysis failed to draw a conclusion that histologic subtype was an independent predictor of PFS. Several explanations are possible for these somewhat contradictory results. Firstly, type 2 PRCC tends to run parallel with high WHO/ISUP grade and high tumor stage and is less strongly related to outcomes than pathologic features. Besides, our study was limited by an overall short follow-up time and a small sample size. The statistical power was weakened by very few events.

Recently, a novel grading system for clear cell RCC and PRCC was proposed by ISUP and then endorsed by the WHO [14, 21]. The applicability of WHO/ISUP grading system to PRCC has been validated and recommended widely $[14,18]$. Cornejo et al. reported that WHO/ISUP grade was statistically superior to Fuhrman grade in predicting survival in both univariate and multivariate analyses [16]. In this study, all samples were regraded according to the four-tiered WHO/ISPU grading system. In accordance with previous studies, we found that WHO/ISUP grade was an independent prognostic factor for PFS.

It is generally recognized that clear cell RCC conveys superior outcome than PRCC. However, different PRCC
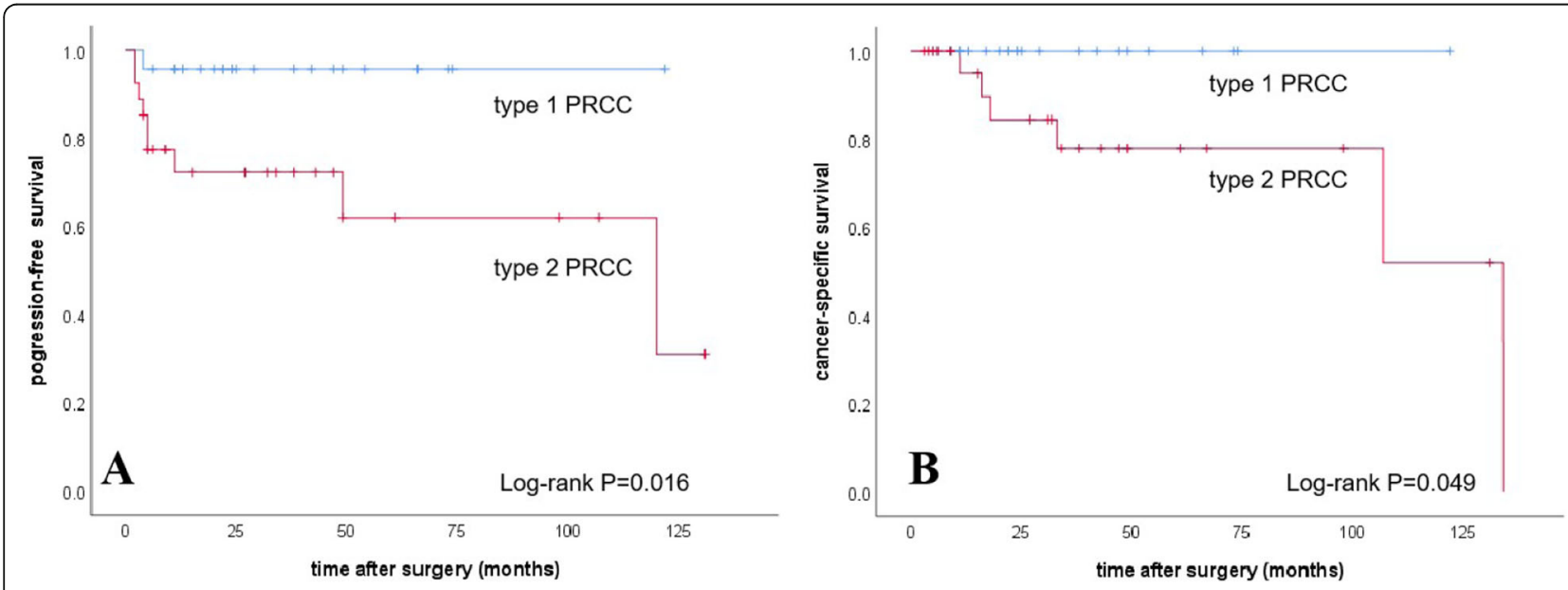

Fig. 2 Kaplan-meier curves. a, progression-free survival. b, cancer-specific survival. P-values are based on log-rank test. PRCC, papillary renal cell carcinoma 
Table 4 Univariate Cox analysis on progression-free survival in papillary renal cell carcinoma patients

\begin{tabular}{|c|c|c|c|}
\hline & HR & $95 \% \mathrm{Cl}$ & $\mathbf{P}$ \\
\hline \multicolumn{4}{|l|}{ Gender } \\
\hline Female & 1 & & \\
\hline Male & 0.364 & $0.095-1.389$ & 0.139 \\
\hline \multicolumn{4}{|l|}{ Age } \\
\hline$\leq 60$ & 1 & & \\
\hline$>60$ & 0.885 & $0.248-3.156$ & 0.851 \\
\hline \multicolumn{4}{|l|}{ Surgical approach } \\
\hline Open surgery & 1 & & \\
\hline Laparoscopic surgery & 0.323 & $0.086-1.205$ & 0.092 \\
\hline \multicolumn{4}{|l|}{ Type of surgery } \\
\hline Partial nephrectomy & 1 & & \\
\hline Radical nephrectomy & 0.092 & $0.012-0.726$ & 0.024 \\
\hline \multicolumn{4}{|l|}{ Cell-based immunotherapy } \\
\hline No & 1 & & \\
\hline Yes & 1.132 & $0.236-5.425$ & 0.877 \\
\hline \multicolumn{4}{|l|}{ Tumor stage } \\
\hline $\mathrm{T} 1 / \mathrm{T} 2$ & 1 & & \\
\hline $\mathrm{T} 3 / \mathrm{T} 4$ & 12.136 & $2.557-57.599$ & 0.002 \\
\hline \multicolumn{4}{|l|}{ WHO/ISUP grade } \\
\hline G1/G2 & 1 & & \\
\hline G3/G4 & 13.692 & $2.890-64.874$ & 0.001 \\
\hline \multicolumn{4}{|l|}{ PRCC subtype } \\
\hline type 1 & 1 & & \\
\hline type 2 & 8.326 & $1.050-66.024$ & 0.045 \\
\hline Tumor size & 1.340 & $1.117-1.608$ & 0.002 \\
\hline
\end{tabular}

Abbreviations: HR Hazard ratio, Cl Confidence interval, WHO/ISUP World Health Organization/International Society of Urological Pathology, PRCC Papillary renal cell carcinoma

risk subgroups may not predict the same prognosis. Steffens and colleagues [3] indicated that PRCC could apparently be differentiated into organ-confined/localised and advanced/metastatic subgroup. Compared to clear cell RCC, the former subgroup had a significantly better prognosis, while the latter subgroup had a worse prognosis. Previous studies have shown that PRCC, especially type 2 PRCC, is an heterogeneous entity with divergent spectra [18]. Hence, our understanding of PRCC should not be limited to histologic subtypes. More information about genome profiles and cell signaling of tumor induction, promotion, and progression is required.

Although our study offers new information in answering the question of prognostic differences between patients with type 1 PRCC and patients with type 2 PRCC, it is not devoid of potential limitations that need to be acknowledged. First and foremost are the limitations inherent to its retrospective nature. In addition, in order to make a homogeneous pathological entity, we only chose those patients between 2007 and 2018, thus the follow-up time and sample size were the limitations of the present study.

\section{Conclusions}

This study compared clinicopathologic parameters and oncologic outcomes between type 1 PRCC and type 2 PRCC in a homogeneous pathological entity. We found that foamy macrophages were more common in type 1 PRCC, while eosinophils and microvascular angiolymphatic invasion were more frequent in type 2 PRCC. Although type 2 PRCC tended to have a higher tumor stage and WHO/ISUP grade, histologic subtype was not an independent prognostic factor. In multivariate analysis, only WHO/ISUP grade and tumor size were significantly associated with PFS.

\section{Abbreviations}

PRCC: Papillary renal cell carcinoma; RCC: Renal cell carcinoma; WHO/ ISUP: World Health Organization/International Society of Urological

Pathology; PFS: Progression-free survival; CSS: Cancer-specific survival

\section{Acknowledgements}

None

\section{Authors' contributions}

$\mathrm{XL}$ and $\mathrm{XW}$ contributed equally to this work and they designed the study, obtained data, performed the statistical analysis, wrote the manuscript and interpreted the data. $\mathrm{HZ}$ participated in the conception and design of the study and acquisition of data. RC and PG participated in the conception and design of the study and interpretation of the data and reviewed and edited the manuscript. All authors read and approved the final manuscript.

Funding

None.

\section{Availability of data and materials}

The data supporting the conclusions used and/or analyzed in this study are available from the corresponding author by request.

Ethics approval and consent to participate

This was a retrospective study approved by the Affiliated Hospital of Xuzhou Medical University review board (NO.XYFY2019-KL032-01). Informed consent was waived.

\section{Consent for publication}

The data do not contain any information that could identify the patient, therefore consent for publication was waived.

\section{Competing interests}

The authors declare that they have no competing interests.

\section{Author details}

${ }^{1}$ Department of Urology, the Affiliated Hospital of Xuzhou Medical University, Xuzhou, Jiangsu, China. ${ }^{2}$ Department of Pathology, the Affiliated Hospital of Xuzhou Medical University, Xuzhou, Jiangsu, China.

Received: 18 June 2019 Accepted: 7 September 2020

Published online: 15 September 2020

\section{References}

1. Srigley JR, Delahunt B, Eble JN, Egevad L, Epstein Jl, Grignon D, Hes O, Moch H, Montironi R, Tickoo SK, et al. The International Society of Urological Pathology (ISUP) Vancouver classification of renal Neoplasia. Am J Surg Pathol. 2013;37(10):1469-89. 
2. Linehan WM, Spellman PT, Ricketts CJ, Creighton CJ, Fei SS, Davis C, Wheeler DA, Murray BA, Schmidt L, Vocke CD, et al. Comprehensive molecular characterization of papillary renal-cell carcinoma. N Engl J Med. 2016;374(2):135-45.

3. Steffens $S$, Janssen M, Roos FC, Becker F, Schumacher S, Seidel C, Wegener G, Thuroff JW, Hofmann R, Stockle M, et al. Incidence and long-term prognosis of papillary compared to clear cell renal cell carcinoma--a multicentre study. Eur J Cancer. 2012;48(15):2347-52.

4. Delahunt B, Eble JN. Papillary renal cell carcinoma: a clinicopathologic and immunohistochemical study of 105 tumors. Mod Pathol. 1997;10(6):537-44.

5. Jiang F, Richter J, Schraml P, Bubendorf L, Gasser T, Sauter G, Mihatsch MJ, Moch H. Chromosomal imbalances in papillary renal cell carcinoma: genetic differences between histological subtypes. Am J Pathol. 1998;153(5):1467-73.

6. Magers MJ, Perrino CM, Cramer HM, Wu HH. Cytomorphologic comparison of type 1 and type 2 papillary renal cell carcinoma: a retrospective analysis of 28 cases. Cancer Cytopathol. 2019;127(6):370-6.

7. Leroy X, Zini L, Leteurtre E, Zerimech F, Porchet N, Aubert JP, Gosselin B, Copin MC. Morphologic subtyping of papillary renal cell carcinoma: correlation with prognosis and differential expression of MUC1 between the two subtypes. Mod Pathol. 2002;15(11):1126-30.

8. Akhtar M, Al-Bozom IA, Al HT. Papillary Renal Cell Carcinoma (PRCC): An Update. Adv Anat Pathol. 2019:26(2):124-32.

9. Pignot G, Elie C, Conquy S, Vieillefond A, Flam T, Zerbib M, Debre B, Amsellem-Ouazana D. Survival analysis of 130 patients with papillary renal cell carcinoma: prognostic utility of type 1 and type 2 subclassification. UROLOGY. 2007;69(2):230-5.

10. Bigot P, Bernhard JC, Gill IS, Vuong NS, Verhoest G, Flamand V, Reix B, Suer E, Gokce I, Beauval JB, et al. The subclassification of papillary renal cell carcinoma does not affect oncological outcomes after nephron sparing surgery. World J Urol. 2016;34(3):347-52.

11. Yamanaka K, Miyake H, Hara I, Inoue TA, Hanioka K, Fujisawa M. Papillary renal cell carcinoma: a clinicopathological study of 35 cases. Int J Urol. 2006; 13(8):1049-52.

12. Lopez-Beltran A, Scarpelli M, Montironi R, Kirkali Z. 2004 WHO classification of the renal tumors of the adults. Eur Urol. 2006;49(5):798-805.

13. Sika-Paotonu D, Bethwaite PB, McCredie MR, William JT, Delahunt B. Nucleolar grade but not Fuhrman grade is applicable to papillary renal cell carcinoma. Am J Surg Pathol. 2006;30(9):1091-6.

14. Moch H, Cubilla AL, Humphrey PA, Reuter VE, Ulbright TM. The 2016 WHO classification of tumours of the urinary system and male genital organs-part a: renal, penile, and testicular tumours. Eur Urol. 2016;70(1):93-105.

15. Delahunt B, Cheville JC, Martignoni G, Humphrey PA, Magi-Galluzzi C, McKenney J, Egevad L, Algaba F, Moch H, Grignon DJ, et al. The International Society of Urological Pathology (ISUP) grading system for renal cell carcinoma and other prognostic parameters. Am J Surg Pathol. 2013;37(10):1490-504.

16. Cornejo KM, Dong F, Zhou AG, Wu CL, Young RH, Braaten K, Sadow PM, Nielsen GP, Oliva E. Papillary renal cell carcinoma: correlation of tumor grade and histologic characteristics with clinical outcome. Hum Pathol. 2015;46(10):1411-7.

17. Schrader AJ, Rauer-Bruening S, Olbert PJ, Hegele A, Rustemeier J, Timmesfeld N, Varga Z, Hofmann R. Incidence and long-term prognosis of papillary renal cell carcinoma. J Cancer Res Clin Oncol. 2009;135(6):799-805.

18. Polifka I, Agaimy A, Herrmann E, Spath V, Trojan L, Stockle M, Becker F, Strobel P, Wulfing C, Schrader AJ, et al. High proliferation rate and TNM stage but not histomorphological subtype are independent prognostic markers for overall survival in papillary renal cell carcinoma. Hum Pathol. 2019;83:212-23.

19. Ha YS, Chung JW, Choi SH, Lee JN, Kim HT, Kim TH, Chung SK, Byun SS, Hwang EC, Kang SH, et al. Clinical significance of subclassification of papillary renal cell carcinoma: comparison of Clinicopathologic parameters and oncologic outcomes between papillary histologic subtypes 1 and 2 using the Korean renal cell carcinoma database. Clin Genitourin Cancer. 2017;15(2):e181-6.

20. Borgmann H, Musquera M, Haferkamp A, Vilaseca A, Klatte T, Shariat SF, Scavuzzo A, Jimenez RM, Wolff I, Capitanio U, et al. Prognostic significance of Fuhrman grade and age for cancer-specific and overall survival in patients with papillary renal cell carcinoma: results of an international multiinstitutional study on 2189 patients. World J Urol. 2017;35(12):1891-7.

21. Delahunt B, Egevad L, Srigley JR, Samaratunga H. Fuhrman grading is inappropriate for papillary renal cell carcinoma. World J Urol. 2018;36(8):1335-6.

\section{Publisher's Note}

Springer Nature remains neutral with regard to jurisdictional claims in published maps and institutional affiliations.

Ready to submit your research? Choose BMC and benefit from:

- fast, convenient online submission

- thorough peer review by experienced researchers in your field

- rapid publication on acceptance

- support for research data, including large and complex data types

- gold Open Access which fosters wider collaboration and increased citations

- maximum visibility for your research: over $100 \mathrm{M}$ website views per year

At BMC, research is always in progress.

Learn more biomedcentral.com/submissions 